\title{
The Effect of Learning Effectiveness and Self-Efficacy on Intermediate Financial Accounting I Learning outcome
}

\author{
Tuhardjo, Dodik Juliardi, Mohamad Arief Rafsanjani, \\ Dudung Ma'ruf Nuris, Department of Accounting, Universitas Negeri Malang
}

\begin{abstract}
This study aims to test the validity of the theories about learning effectiveness that has been proposed by Slameto (2010), Marzano (1993), Brooks and Brooks (1993), Thomas and Rohwer in Slavin (1991), which stated that the learning effectiveness affects the learning outcome. The study also aims to confirm the selfefficacy theory proposed by Bandura (1997) and Walsh in Salkind (2008) that self-efficacy influences on learning outcomes. This study uses a quantitative approach. The population in this study is the students of Accounting Department, Faculty of Economics, Universitas Negeri Malang (State University of Malang) who are taking intermediate financial accounting 1 on the odd semester of 2015/2016 academic year with 155 students as samples.The findings in this study show that the learning effectiveness and self-efficacy have positive and significant impact on intermediate financial accounting 1 learning outcomes. Other findings also show that the learning students' effectiveness and self-efficacy also have a relationship with the background of the majors on the level of previous education. The suggestions which can be given on the results of this study are: (1) for the lecturers at the Department of Accounting, Faculty of Economics State University of Malang should be able to understand and design learning that can foster an effective way of learning and growing selfefficacy in one self; (2) for students majoring in Accounting at Faculty of Economics, Universitas Negeri Malang should continue to improve the way of learning and growing level of confidence in one self; and (3) for further research is recommended using other variables that have not been studied as learning style, intelligence, and career interests, as well as using a qualitative approach on the phenomenon that can dig deeper and detail associated with improved learning outcomes of accounting.
\end{abstract}

Keyword: Learning Effectiveness, Self-Efficacy, Learning Outcome

\section{INTRODUCTION}

Gredler (2011) stated that, for individuals, the study of learning can explain about the acquisition of the various abilities and skill on a strategy to implement role in life and the attitudes and values that guide the actions for a person. Given the importance of learning for communities and individuals, of course, we cannot allow the process of education (learning and teaching) takes for granted. (Gredler, 2011), stated that it takes a certain learning system for implementing cultural values and prepare the younger generation to take over the productive role of their predecessors.

Effective learning emphasizes the importance of learning as a personal process, where each student builds knowledge and personal experience (Marzano, 1993). Knowledge and personal experiences are built by each student through interaction with the environment. Student / students themselves who construct meaning about the things he had learned (Brooks and Brooks, 1993). Clough and Clark also stated that the knowledge that built itself has the advantage of easy to remember, easy to understand and transformed, so that students will be able to give the correct answer if they are given the question related to the problems faced.

Uno (2011) stated that learning is considered effective if the score achieved through learning outcomes meet the minimum competency. Miarso (in Uno, 2011) stated that and effective learning is learning that can generate useful learning and focused on students (student-centered) through the use of appropriate procedures.

Other factors that affect learning outcomes is an internal factor. One of internal factor that plays an important role here is self-efficacy. Walsh in Salkind (2008), said that over the past several decades, educators and educational psychologists have been interested in students' self-perceptions and self-efficacy. Self-efficacy is defined as an expectation that one holds regarding one's capabilities to accomplish a particular task or goal. In a most general and perhaps somewhat rough sense, self-efficacy might be thought of as a sense of confidence to act successfully. Self-efficacy is an individual's beliefs about her ability to perform a task or action needed to achieve a particular result (Ghufron and Risnawita, 2014: 73). Bandura (1997, 2000, 2001) believes that selfefficacy is an important factor affecting students' achievement. 


\section{The Learning Effectiveness}

\section{LITERATURE REVIEW}

Learning is a process of mental activity of a person in interacting with the environment, resulting in a change in behavior that is a good positive changes in knowledge, attitudes, and psychomotor (Sanjaya 2008). The learning process will produce a change in behavior. Effective learning emphasizes the importance of learning as a personal process, where each student builds knowledge and personal experience (Marzano, 1993). Knowledge and personal experiences are built by each student through interaction with the environment. Student / students themselves who construct meaning about the things he had learned (Brooks and Brooks, 1993). Thus, learning must be able to orient the students to be able to play its role in the life to come through the skills, knowledge, attitudes, and skills possessed by the more meaningful. Slameto (2010) suggested that learning how bad factor is the cause was still sufficient number of students who are actually clever but only achievement that is no better than students who are actually less intelligent but capable of high achievement because it has a better way of learning.

Thomas and Rohwer (in Slavin, 1991) have proposed a set of principles of effective learning that apply across particular learning methods. These are as follows:

1. Specificity: study strategies must be appropriate to the learning objectives and the types of students with whom they are used. For example, research has found that the same strategies work differently with older and younger student, or with high and low achievers. Writing summaries for others to read may, theoretically, be an affective study method, but it is probably too difficult for young children.

2. Generativity: one of the most important principles of effective study strategies is that they should involve reworking the material studied, generating something new. This activity forces student as to engage in a high level of mental processing, which probably mush occur for any study strategy to be effective. Examples of strategies that use a high degree of generativity are writing summaries and generating questions for others, organizing notes into outlines, diagramming relationships among main ideas and teaching partners about text contents. Strategies low in generativity, such as indiscriminate underlining, taking notes without having to identify main ideas, or writing extensive summaries without having to focus on what in important, have been less successful in helping students learn.

3. Executive monitoring: the principle of effective monitoring simply means that students should know how and when to apply their study strategies and how to tell if they are working for them.

4. $\quad$ Personal efficacy: students must have a clear sense that learning will pay off for them if they work hard at it. Teachers can create a sense that learning will pay off by giving frequent quizzes and tests based directly on the material that students have studied and by making performance on these assessments a major portion of students' grades.

\section{Self-Efficacy}

Salkind (2008), said that a very large body of research literature demonstrates that self-efficacy is an important predictors of human performance across a vast array of task and settings. Self efficacy has become a central construct in understanding human change and its promotion. Moreover, Salkind (2008), point out that over the past several decades, educators and educational psychologists have been interested in students' selfperceptions and self-efficacy. Self-efficacy is defined as an expectation that one holds regarding one's capabilities to accomplish a particular task or goal. In a most general and perhaps somewhat rough sense, selfefficacy might be thought of as a sense of confidence to act successfully.

The term self efficacy according to Bandura (1997) in Alderman (2004:69) is "self-efficacy refers to beliefs in one's capabilities to organize and execute the courses of action required to produce given attainments". "It is defined as an expectation that one hold's regarding one's capabilities to accomplish a particular task or goal" Ghufron and Risnawita (2014: 73) defined self-efficacy as an individual's beliefs about her abilities in conduct tasks or actions required to achieve a particular result. "Self-efficacy is the sense of the ability to do a task" (Myers, 2012: 72). More specifically, Harahap (2011: 43) defines a student self-efficacy is the belief of the student to determine how she feel, think, motivate and behave. Based on some sense it can be concluded that self-efficacy is the belief the individual's ability to do things in order to achieve the desired results.

According to Walsh in Salkind (2008) self-efficacy of the students can be enhanced in four ways:

(1) by directly experiencing the mastery of classroom tasks; (2) by witness the mastery demonstrations of others as they are engaged in academic work; (3) by hear the encouraging words of teachers and partners who exhort them to persist in meeting academic challenges; and (4) students' efficacy beliefs may be affected by their physiological state (their perceptions of physiological agitation, heart rate, breathing rate, and so on.

Individuals with high self-efficacy believe that they can do something to change the events around him. When individuals with high self-efficacy failure, he will try harder to overcome the challenges. On the other hand, 
individuals with low self-efficacy considers himself basically not able to do everything that was around him, so that when a failure he tends to give up easily.

Bandura (1997) stated that each individual has self-efficacy are different from each other based on the three-dimensional (Ghufron and Risnawita, 2014), namely:

\section{a. Dimension of Level}

This dimension relates to the degree of difficulty of the task when the individual feels able to do it. If individuals faced with tasks that are arranged according to the degree of difficulty, the individual self-efficacy may be limited to tasks easy, medium, or even covers the tasks most difficult, according to the perceived limits to meet the demands required behavior at each level. This dimension has implications for the selection behavior will be attempted or avoided. Individuals will try behavior were deemed capable of doing and avoid behavior that is outside the limits of felt.

\section{b. Dimension of Strength}

This dimension relates to the power level of individual beliefs or expectations about its capabilities. The hope of the weak easily swayed by experiences that do not support. Instead, the hope that steady encourage individuals persist in his efforts. Although it may be found the experience lacking. This dimension is directly related to the level dimensions, such as the higher the level of difficulty of the task, the weaker the confidence that is felt to complete.

\section{c. Dimension of Generalization}

This dimension is related to the broad areas of behavior in which the individual feels confident in his ability. Individuals can feel confident about her abilities. Are limited to a particular situation or activity and in a series of activities or situations that vary.

According to Bandura (Alwisol 2008; Ghufron and Risnawita, 2014), self-efficacy can be obtained, modified, upgraded, or downgraded, through one or a combination of four sources as follow:

\section{Performance Experience}

Performance experience is the achievement that has been achieved in the past. These resources provide the most powerful influences on self-efficacy because it is based on personal experience as a real individual in the form of success and failure. Successful experience will boost self-efficacy, while failure will lower it down. After the self-efficacy develops through a series of successes, the negative impact of the common failures will be reduced. In fact, then failure will be overcome with specific effort to strengthen the self-motivation if someone finds through experience that the most difficult obstacles can be overcome through persistent effort.

\section{Vicarious Experience}

Vicarious experience is gained through the social model such as observation of the success or failure of others. Observations on the success of others with comparable capabilities in doing a task will improve the efficacy of the individual self in the same task. In contrast, observations of the failure will reduce the ability of individual assessments and individual will reduce the work done, even so these individuals are not going to want to do things that do figure that he observed in the long term. However, if the figures are observed are considered to have different capabilities with self-observer, the effect would not be great vicarious.

\section{Verbal Persuasion}

Self-efficacy can also be obtained, amplified or attenuated through verbal persuasion. This persuasion may be suggestions, advice, and guidance that can increase an individual's belief about its ability to achieve the desired objectives. According to Bandura, the influence of persuasion is not too large. Even in conditions that suppress and continuous failure, the influence of persuasion will be eliminated. This is because persuasion does not provide an experience that can be directly experienced or observed individuals. In addition, the influence of persuasion also depends on the confidence of the individual against the giver of persuasion, and the realistic nature of what has been persuaded.

\section{The State of Emotions}

Individuals will base information about their emotional stated to assess their abilities. Strong emotions, fear, anxiety, stress in stressful situations an individual is seen as a sign of incompetence because it may weaken the efficacy of himself. Yet, it could happen, the increased emotion (moderation) can increase self-efficacy. 


\section{Learning Outcomes}

McMillan (2007a), Nitcko \& Brookhart (2007) in Kauchak and Eggen (2011) suggested that the assessment is the process teachers use to gather information and the make decisions about students' learning and development. Slavin (1991) suggested that some of the objectives of the evaluation include: (a) incentives to increase of students' effort; (B) feedback to students; (C) feedback to teachers.

According to Skinner in Riwayati (2013: 21), the learning outcomes are changes in behavior that occur after the individual learning process. "The result is a learning abilities of the students after receiving their learning experience" (Sudjana, 2011: 22).

Dimyati and Mudjiono (2006: 20) defined learning outcomes as the pinnacle of the learning process, while learning is a set of cognitive processes that change the nature of environmental stimuli with the passing of information processing into new capabilities. Bloom classify learning outcomes into three domains, namely cognitive, affective, and psychomotor domains. According Sudjana (2011:2), the third sphere became the object of assessment of learning outcomes, but the realm of cognitive is most widely assessed by teachers at the school as it relates to the student's ability to master the content of teaching materials. Here's a brief description of the three domains of learning outcomes by those Bloom (Sudjana, 2011: 22).

Cognitive domain with respect to the results of intellectual learning that consists of six aspects, namely the knowledge or memory, comprehension, application, analysis, synthesis, and evaluation. Both the first aspect of cognitive called low level and the next four, including high-level cognitive. Affective domain regarding the attitude of five aspects such as acceptance, reply or reaction, assessment, organization, and internalization.

Psychomotor domain of the outcomes of learning skills and ability to act. There are six aspects of psychomotor domains that are: (a) reflex, (b) the basic movement skills, (c) perceptual ability, (d) the harmony or accuracy, (e) the movement of complex skills, and (f) the movement of expressive and interpretive.

\section{RESEARCH METHOD}

This study uses a quantitative descriptive approach. This research is expected to provide an explanation of how to influence the learning effectiveness and self-efficacy on learning outcomes, as discussed in theoretical arguments. This research was conducted in the $5^{\text {th }}$ semester student in 2015/20016 academic year of Accounting Education and Accounting Department at Faculty of Economics State University of Malang. The population is 231 students that was taken through simple random sampling by using the formulations obtained through Terrel Danniel and 135 students study sample. Data analysis method used is multiple regression.

The independent variables in this study is the learning effectiveness (X1) and self-efficacy (X2). The dependent variable is the learning outcomes $(\mathrm{Y})$. Relations between variable this study can be described as in the following figure

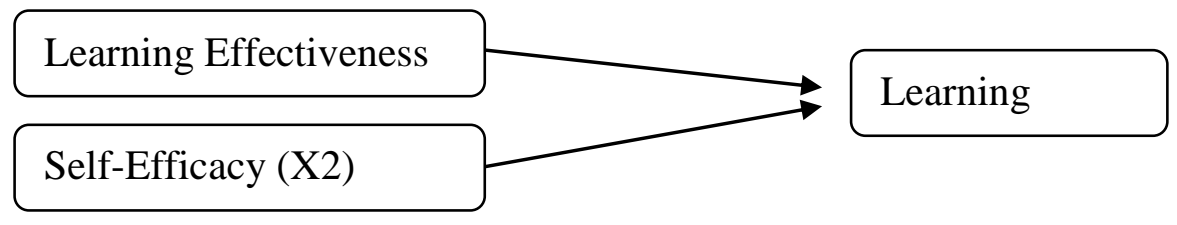

Figure 1 The Relationship of Independent Variable with Dependent Variable

\section{FINDINGS AND DISCUSSION}

Descriptively, research findings point of the sample used, illustrate that most students have a low learning effectiveness. It is shown from the data distribution of $54.84 \%$ has a low learning effectiveness, while having a higher efficacy is only $34.84 \%$, as seen in figure 2 below. 


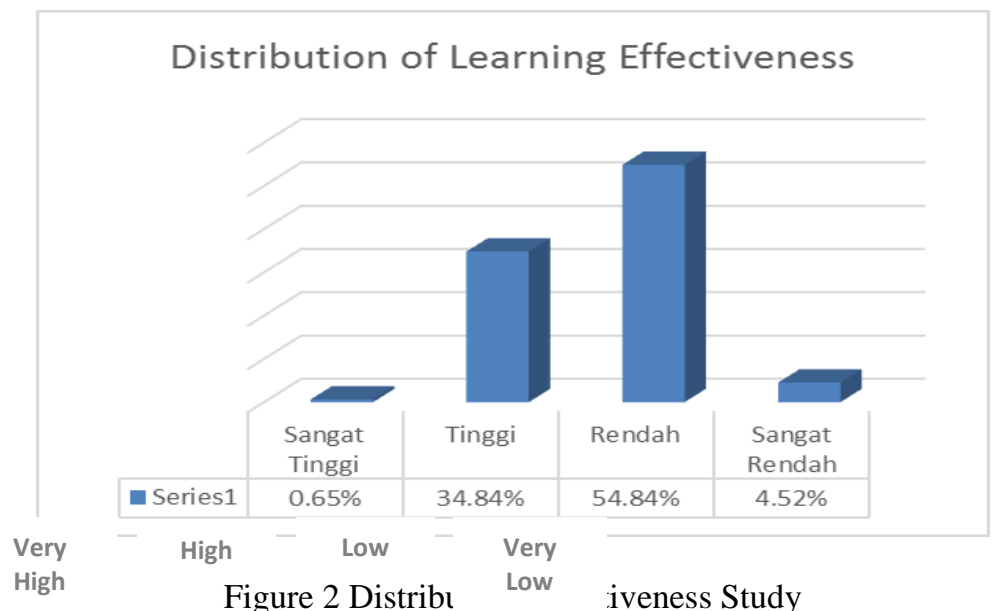

For a description of the variable self-efficacy also showed that $51.61 \%$ of the students were selected as sample had a low level of self-confidence, and $41.94 \%$ have a high confidence level, and a small percentage is $1.29 \%$ have a very high confidence level and $5,16 \%$ is very low. This shows that students who are low on confidence level capabilities possessed still dominates.

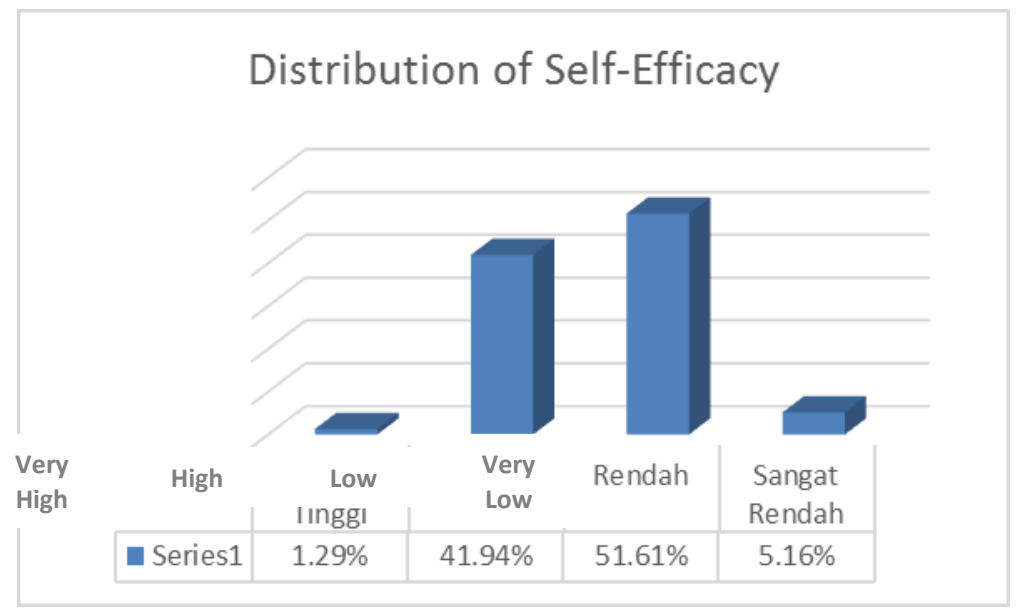

Figure 3 Distribution of Self-efficacy

Intermediate financial accounting I learning outcomes also shows that only $44.52 \%$ who earn good grades (minimum B), while the rest obtained under B. or in other words more than $50 \%$ are getting less value (below B).

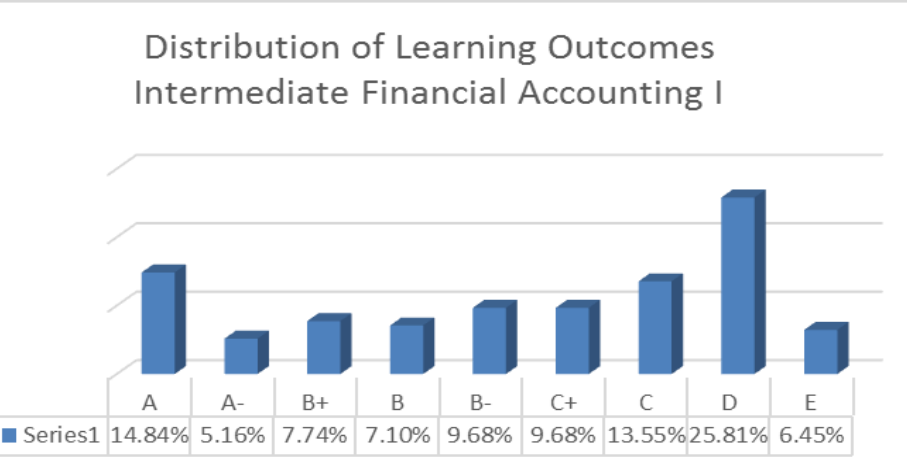

Figure 4 Distribution of Learning Outcomes Intermediate Financial Accounting 1

Another interesting finding emerged when researchers sought to compare the background majors taken in high school before. The results of the comparison between students coming from high school showed no big difference between students from majoring in science and social studies. They both have a low learning 
effectiveness, low confidence levels and Intermediate financial accounting I learning outcome is also unsatisfactory (below B). It can be seen in the following graph.

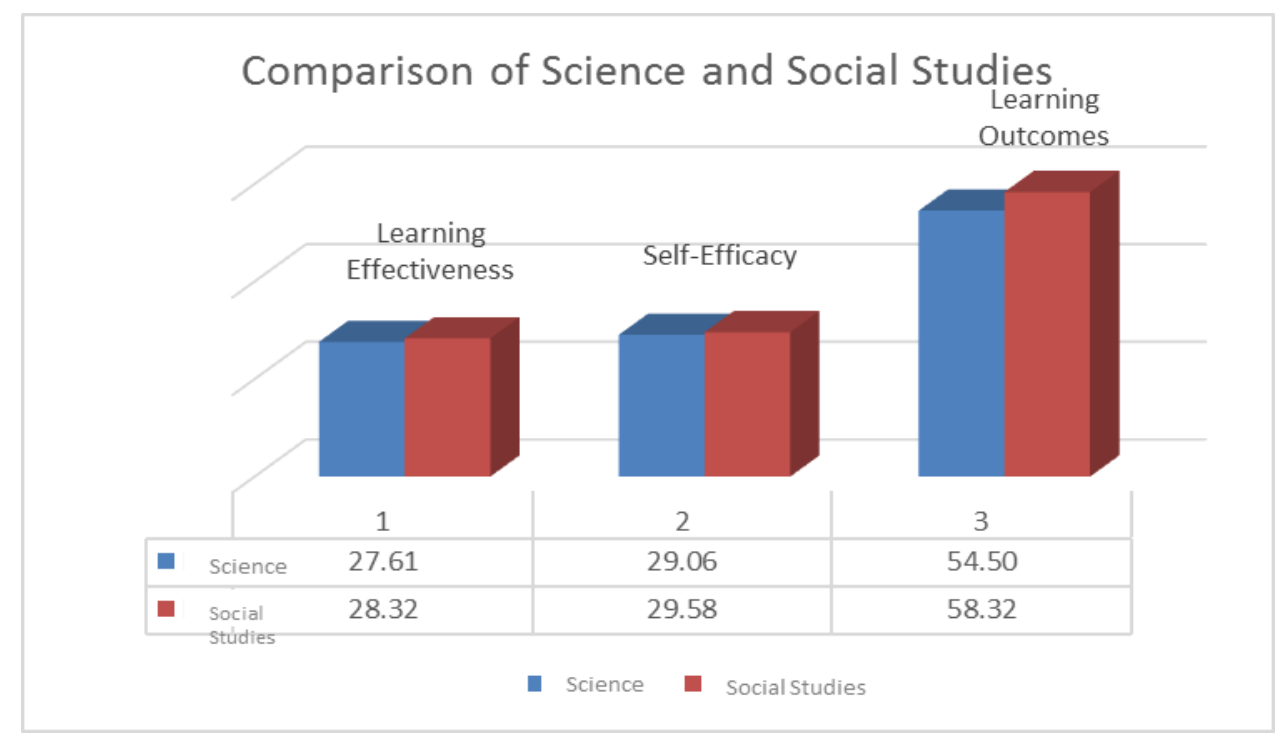

Figure 5 Comparison of Science and Social Studies

Different findings would occur when the researchers compared between students from Accounting vocational high school and Non Accounting vocational high school. Students coming from the accounting department has a high learning effectiveness, confidence levels are too high, and the average gain scores good learning results (A). Meanwhile, the students who come from non-accounting majors (in this sample there are some students who come from software engineering majors) have the opposite result. They have a low learning effectiveness, confidence level is too low, and average only received grades of B-.

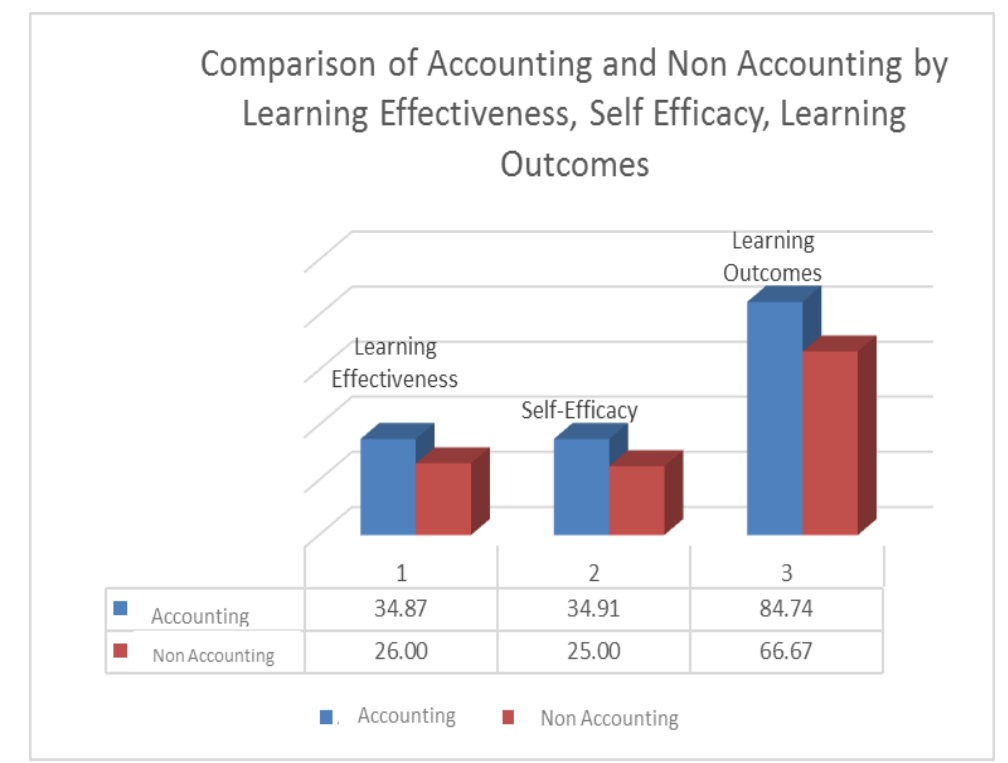

Figure 6 Comparison of Accounting Vocational High School and Non Accounting Vocational High School

Results of testing the hypothesis, it is known that the variable learning effectiveness have a significance level of $<0.01$ and a positive coefficient. This indicated that the first hypothesis (H1) in this study received at a significance level of $1 \%$, meaning that there is a significant positive influence on the learning effectiveness for Intermediate Financial Accounting I course learning outcomes. The same thing happened in the variable selfefficacy which have a significance level of $<0.05$ and a positive coefficient. This shows that the second hypothesis (H2) in this study received at a significance level of 5\%, meaning that there is a significant positive effect of self-efficacy for learning outcomes Intermediate Financial Accounting 1. Hypothesis test results shown in the following table. 
Table 1 Output of Multiple Regression Test Coefficients

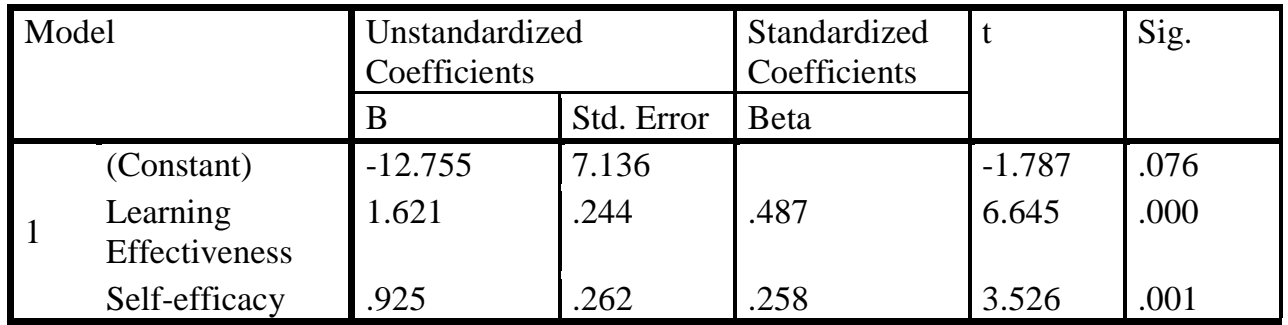

a. Dependent Variable: Intermediate Financial Accounting 1 Learning Outcome

\section{The Effect of Learning Effectiveness on Intermediate Financial Accounting 1}

Based on the analysis of data, there is evidence that there is a significant positive effect between the learning effectiveness for Intermediate Financial Accounting 1 learning outcomes. Descriptive analysis showed that of the sample is taken, the majority of students (54.84\%) had a low learning effectiveness, and only $34,84 \%$ have a high learning effectiveness. From the results of study showed that more than $50 \%$ of students obtain unsatisfactory results (under B).

This certainly proves the opinion expressed by Slameto (2010), which revealed that the effect on student learning achievements. Where the research data show that when students do not have an effective way of learning, the achievement of learning outcomes obtained are also unsatisfactory.

Marzano (1993) suggested that effective learning emphasizes that learning is a personal process, where students construct their own knowledge and experience. The same thing also expressed by Brooks and Brooks (1993) that the student / students themselves who construct meaning about the things learned. Opinions that are highlighted in the learning process there are ways or approaches, actions that will determine the success or achievements to be obtained. These statements evidenced in this study, the results of the collection and analysis of data shows that students who do not have learning effectiveness in obtaining learning outcomes are unsatisfactory (under B).

Thomas and Rohwer in Slavin (1991) suggests there are three principles of effective learning, specificity, generativity and monitoring executive. The data collected in this study showed many students still do not know will learn what and what you want to gain from the learning process, so that they also cannot determine strategy or way of learning the right (study strategies must be Appropriate to the learning objectives and the types of students), and of course in the end the results or outcomes of learning acquired also unsatisfactory. Thomas and Rohwer clearly suggests that one of the principles of effective learning is learning strategies must be adapted to the learning objectives and types of learners themselves (specificity principle).

Other findings in this study also shows that many students who can eventually understand and get something or new capabilities after experiencing the learning process (they should involve; reworking the material studied, generating something new). This causes many students who obtain a score or a good learning outcomes. It is consistent with the theory put forward Thomas and Rohwer, that in an effective learning process, one must be able to produce something new (generativity principle).

This study also proved effective learning principles of Thomas and Rohwer, that students should know how and when the time is right to use learning strategies (how and when to apply Reviews their strategies) that they have. This study shows that students who receive unsatisfactory learning outcomes do not know what to do and how when faced with a problem or cases in Intermediate Financial Accounting 1 course (executive monitoring principle).

From the results of an explanation from the lecturer of the course also shows that there are still many students who do not understand the concept, application, and procedures in Intermediate Financial Accounting 1 as a result of their inability to adjust strategies or learning objective or competency to be achieved. In the end it impacts on the acquisition of learning outcomes are unsatisfactory. This shows that their ignorance caused by ineffective way of learning which resulted in the achievement of learning outcomes.

In addition to proving the theories put forward by Slameto (2010), Marzano (1993), Brooks and Brooks (1993), and Thomas and Rohwer in Slavin (1991), the results of this study also reinforces previous research conducted by Johantoro (2013) which suggests that the learning effectiveness is significant and positive impact on learning achievement.

At the end of this study shows that when learning is done by constructing knowledge in a personal manner and appropriate learning strategies, the knowledge that is built to be easy to remember, easy to understand and easily transformed or applied that ultimately makes a person will be able to find appropriate solutions for problems encountered in studying the course Intermediate Financial Accounting 1. 


\section{The Effect of Self-Efficacy on Intermediate Financial Accounting 1 Learning Outcome}

Based on the analysis of data, there is evidence that there is a significant positive effect between self-efficacy for learning outcomes Intermediate Financial Accounting 1. Descriptive analysis showed that of the sample taken, more than $50 \%$ of students have a low confidence level. From the study results obtained also showed that more than $50 \%$ of students obtain unsatisfactory results (below B). It is certainly proved the opinion expressed by Bandura that self-efficacy is an important factor affecting student achievement.

The results also showed that when students have difficulty in learning the material Intermediate Financial Accounting 1, most of them are not trying persistent to seek and find a solution. The same thing is also shown that when they have problems or tasks of lecturers with a high level of complexity, the majority of them choose to locate or copy answers from classmates who have found the answer. These things prove that lack the level of confidence in yourself that ultimately result in learning outcomes of learning are unsatisfactory. This finding is consistent with the dimensions (level) on self-efficacy stated by Bandura (1997) that the dimensional level with regard to the degree of difficulty of duty when individuals feel able to do so.

The results of this study also showed that most students still lack confidence in the ability of themselves. This is evident in the exposure of a lecturer of the subjects that often have behaviors that indicate insecurity, such as the implementation of the test, it was found that many students scrambling seating positions that are considered beneficial to commit fraud. This is related to the power level of an individual's belief about his abilities. In the theory of Bandura (1997). It is included in the dimensions of strength (strength dimension).

Yet, other findings also show that there are very few students who are ready and confident to find a solution would be problems or complex problems in the course Intermediate Financial Accounting 1. When faced with the task, quiz or about sudden, they will be ready and confident of being able to finish with good. And they are always ready and confident this get satisfactory academic results. This is certainly in line with the theory of Bandura (1997) that one of the dimensions of self-efficacy is the generality dimension, where these dimensions associated with a field in which the individual feels confident in his ability.

Descriptive analysis showed that the level of confidence of students from SMK Accounting Department at the high category, while students from other than the (high school and vocational nonaccounting) have high levels of low confidence at the moment working on the problems or tasks. The same is also shown results of their study, the student whose background SMK Accounting Department obtain a higher value $(\mathrm{B}+, \mathrm{A}-$, and $\mathrm{A})$, whereas students whose background other than that, in general obtain a better learning outcomes low $(\mathrm{B}+$ downwards). These findings indicate there is relationship between experiential learning (educational background) in / the past and the level of confidence and achievement of learning outcomes at this time. This proves the truth of Bandura's theory which stated that one of the sources of self-efficacy is the experience of performance or experience and previous achievements in the past (performance experience).

Some students in the study also revealed that the spirit and the confidence they are more motivated when seeing the success of classmates who get good grades. They also argued that the guidance, advice and suggestions obtained from classmates and lecturers also improve self-confidence and belief that in fact they can and are able to understand and solve problems in Intermediate Financial Accounting 1course. Two this further confirms the theory of Bandura, that in addition to experience performance (past), the level of one's confidence also comes from vicarious experience (observation of the success of others), and verbal persuasion (suggestions, advice and guidance from others).

Walsh in Salkind (2008) stated that the confidence levels of students can be improved little by little to involve students directly in the control or the completion of tasks in the classroom. This means that when the pupil / student is given direct experience to do the tasks, will provide experience for students / student who can ultimately improve their confidence. Statement Walsh is evident in this study, where the more the intensity of the tasks or problems AKM 1 is given to the students, making them increasingly trained to solve problems, thus making their confidence is increasing in the work tasks or problems Intermediate Financial Accounting 1 (direct experience).

Some students also increased confidence when seeing the success achieved by classmates. This happens because they are inspired by the success of it; they assume when others are able to succeed, then I also can do it. This finding is consistent with the statement of Walsh that increase self-efficacy also because students are inspired by the success of others (witness the mastery demonstration of others).

Provision of guidance, encouragement, advice and suggestions from others also make increasing student confidence. They are becoming increasingly believed in his abilities when dealing with problems or complex tasks in Intermediate Financial Accounting 1 course, after receiving guidance, encouragement and advice from others including the teachers. In addition, their confidence level is also influenced by psychological conditions they experience. As expressed in the findings of the lecturer of Intermediate Financial Accounting 1 course which shows that there are some students who experience a decrease in self-confidence when there are modifications to the exam from the examples and exercises are given. This causes disruption of psychological students, causing a decline in confidence and in the end they did act improperly in the execution of the exam. 
Thus, this study in addition to prove the truth of the theories proposed by Bandura (1997) and Walsh in Sal kind (2008), this study also reinforces the findings of previous studies conducted by Marhaeni (2008), Harahap (2011 and Nurhasnah (2013) which showed that self-efficacy has significant positive effect on learning outcomes.

\section{CONCLUSION AND RECOMMENDATION}

Based on the analysis and discussion, it can be concluded that: the learning effectiveness has positive and significant impact on learning outcomes for Intermediate Financial Accounting 1 Course. This shows that the effectiveness of learning, learning outcomes gained increasing; and vice versa. Self-efficacy has a positive and significant impact on learning outcomes for Intermediate Financial Accounting 1 Course. This suggests that higher levels of student confidence will increase the owned ability, increasing learning outcomes; and vice versa.It is suggested to lecturers in the Department of Accounting Faculty of Economics, State University of Malang can understand and stimulate learning that foster an effective way of learning and growing self-efficacy in students' personality. This is due to learning effectiveness and student confidence level plays an important role in the achievement of learning outcomes. Then, for the Accounting students from Department of Economics at State University of Malang should maintain to improve the way of learning and growing level of confidence in their capabilities.

\section{REFERENCES}

[1] Bandura, A. (1997). Behavior Theory and Indemnificatory Learning. American Journal of Orthopsychiatry, 33, 591-601.

[2] Bandura, A. (2000). Personal Efficacy in Psychobiologic Functioning. In G. V. Caprara (Ed.), Bandura: A Leader in Psychology (pp. 43-66). Milan, Italy: Franco Angeli.

[3] Bandura, A., Adams, N. E., \& Beyer, J. (2001). Cognitive Processes Mediating Behavioral Change. Journal of Personality and Social Psychology, 35, 125-139.

[4] Brooks, Jacqueline Grennon; Brooks, Martin G. 1993. In Search of Understanding: The Case Constructivist Classrooms. Alexandria, Virginia: ASCD.

[5] Dimyati dan Mudjiono, 2006 Belajar dan Pembelajaran. Jakarta: Rinika Cipta

[6] Ghufron, N.M. \& Risnawita. 2014. Teori-teori Psikologi. Jogjakarta: Ar-Ruzz Media

[7] Gredler, Margaret, E, 2011, Learning and Instruction- Teori dan Aplikasi, Edisi keenam. Prenada Media Group, Jakarta

[8] Harahap, Dakkal, 2011, Analisis Hubungan antara Efikasi-Diri Siswa dengan Hasil Belajar Kimianya, Jurnal Jurusan Pendidikan Kimia UMTS, Padangsidimpuan

[9] Kauchak, D \& Eggen, P. 2011 Introduction to Teaching: Becoming a Professional. (4 ${ }^{\text {th }}$ ed.). Upper Saddle River, NJ: Pearson Education.

[10] Marzano, R.J., Pickering, D, Mctighe, J. (1993) Assesing Student Outcomes: Performance Assessment Using the Dimension of Learning Model. Alexandria; Association for Supervision and Curriculum Development

[11] Marhaeni, A.A.I.N. 2008. Determinasi Beberapa Faktor Afektif yang Mempengaruhi Keberhasilan Belajar Mahasiswa Jurusan Pendidikan Bahasa Inggris Universitas Pendidikan Ganesha.Jurnal Pendidikan dan Pengajaran UNDIKSHA No. 3 (733-753)

[12] Nurhasnah. 2013. Pengaruh Lingkungan Keluarga dan Efikasi Diri terhadap Hasil Belajar Produktif Akuntansi Siswa Program Kehlian Akuntansi Smk Bukittinggi. Skripsi Tidak Diterbitkan. Padang: Universitas Negeri Padang

[13] Salkind, Neil J, 2008, Encyclopedia of Educational Psychology, Volume 1\&2, Sage Publication Inc. California

[14] Slameto, 2003, Belajar dan Faktor-faktor yang Mempengaruhinya, Rineka Cipta, Jakarta.

[15] Sanjaya. 2008 Strategi pembelajaran Berorientasi Standar Proses Pendidikan. Jakarta: Prenada Media

[16] Slavin E. Robet1991, Educational Psychology, third edition, A Division of Simon and Schuster inc, United Stated of America

[17] Sudjana, Nana. 2011. Dasar-dasar proses Belajar Mengajar. Bandung: Sinar Baru

[18] Uno, Hamzah B \& Nurdin Mohamad. 2011. Belajar dengan Pendekatan PAILKEM. Jakarta: Bumi Aksara 